\title{
Comparative Growth Parameters and Feed: Gain Ratio of Pure- and Inbred Nigerian Indigenous Chickens
}

\author{
${ }^{*}$ Cosmas C. Ogbu ${ }^{1}$, Eugene N. Nwachukwu ${ }^{2}$ and Sylvanus I. Omeje ${ }^{3}$ \\ ${ }^{I}$ Department of Animal Health and Production, College of Veterinary Medicine, Michael Okpara University of \\ Agriculture, Umudike, Abia State, Nigeria. \\ ${ }^{2}$ Department of Animal Breeding and Physiology, College of Animal Science and Animal Production, Michael \\ Okpara University of Agriculture, Umudike, Abia State, Nigeria. \\ ${ }^{3}$ Department of Animal Science, University of Nigeria, Nsukka.
}

\begin{abstract}
The objectives of the study were to evaluate and compare the growth performance (body weight, $B W T$, and body weight gain, $B W G$ ), feed intake (FI) and feed:gain $(F: G)$ of $G_{1}$ and $G_{2}$ generations of inbred Nigerian indigenous chickens (NIC). A total of 500 chicks (250/generation) were used for the study. The $G_{1}$ birds were produced from sire families established from a base population of random breeding NIC whereas the $G_{2}$ birds were progenies of half and full sib matings involving the $G_{1}$ population. Result showed significant $(P<$ $0.05)$ sire and line effects for $B W T$ in $G_{1}$ and $G_{2}$ generations, respectively. Feed intake did not vary much between sire groups $\left(G_{1}\right.$ generation) but varied without a definite trend between sire lines in $G_{2}$ generation. Differences between sire group and their progenies were non-significant in most of the parameters except for $B W T$ at hatch and $12 \mathrm{wk}$ of age $\left(G_{1} S_{1}\right.$ vs $G_{2} L_{1}: 27.06 \pm 0.41$ vs $24.42 \pm 0.29 \mathrm{~g}$ and $671.42 \pm 19.66 \mathrm{vs} 619.85 \pm$ $18.60 \mathrm{~g}$, respectively), and at $w k 16$ and $20\left(G_{1} S_{2} v s G_{2} L_{2}\right.$ for wk $16: 794.33 \pm 22.58$ vs $741.93 \pm 18.50 \mathrm{~g}$ and $G_{l} S_{4}$ vs $G_{2} L_{4}$ for wk 20: $950.98 \pm 22.05$ vs $\left.888.33 \pm 18.50 \mathrm{~g}\right)$. For feed intake, significant differences were observed at wk 4 and $20\left(G_{1} S_{5}\right.$ vs $G_{2} L_{5}: 17.84 \pm 0.46$ vs $21.64 \pm 0.63 \mathrm{~g}$ and $84.78 \pm 1.80$ vs $90.16 \pm 1.87 \mathrm{~g}$, respectively). Comparison between $G_{1}$ and $G_{2}$ generations for growth parameters was significant for $B W T$ at hatch, 12 and 20 wk of age ( $\% \Delta=-4.95^{*},-3.91$ and -4.00 , respectively, $\left.P<0.05\right)$, FI at wk 4 and $20(18.66 \pm 0.24$ vs $20.20 \pm$ $0.29 ; \% \Delta=8.50^{*}$ and $88.94 \pm 0.90$ vs $92.78 \pm 0.81, \% \Delta=4.32^{*}$, respectively, $\left.P<0.05\right), B W G$ and $F: G$ across the age periods (range: -13.72 to $-24.97 \%$, and 19.93 to $27.97 \%$, respectively, $P<0.05$ ). It was concluded that inbreeding could be used to establish sire lines to be used in crosses for the improvement of productive traits in populations of NIC.
\end{abstract}

Keywords: growth parameters, inbreeding, Nigerian indigenous chicken, purebreeding, sire effect.

\section{Introduction}

Indigenous chickens play important roles in the supply of animal protein and income to the rural populace [1]. These birds also possess valuable genetic potentials for production and adaptation acquired over years of natural selection and evolution. These genetic attributes are beneficial and indispensable for sustained production under low input and continuously changing environments $[2,3,4]$. Integrating the NIC into a target gene pool required for organized and sustained poultry production and breeding in Nigeria will enhance the infusion of these adaptive genes into the National germplasm for present and future uses. To achieve this, the NIC must be 'purified' that is, made homozygous at loci controlling most of the productive and adaptive traits [5]. Carefully planned and coordinated inbreeding (mating of individuals related by descent) or within line/family breeding (involves inbreeding) provides ready means of achieving this. Inbred lines are known to be homozygous for favourable genes at most loci (depending on the level of inbreeding) [5] and to manifest positive heterosis when genetically divergent lines from different genetic backgrounds are intercrossed $[5,6,7]$. Again, inbred lines allow the unlimited production of animals of the same genotype for repeated genetic evaluation and phenotypic characterization [5]. Performance of purebred and inbred genotypes are therefore more predictable when compared with randombred or terminal products in which most productive genes are at intermediate frequencies or unfavourable genes masked by dominant alleles [8, 9]. Lonergan et al. [10] exploited inbred Leghorn and Fayoumi lines for the study of breast meat quality and composition. Inbred lines of Fayoumi, White Leghorn and New Hampshire have also been employed for genetic studies of production traits $[11,12]$. Purebreeding/inbreeding concentrates favourable genes and reveals deleterious genes which are eliminated through natural or artificial selection. Subjecting the NIC to systematic inbreeding could hence reveal unproductive genes which could be selected against, as well as concentrate favourable ones leading to improved performance. The objectives of the present study were therefore to produce and evaluate two generations (a purebred and an inbred generation) of NIC for growth parameters (body weight, BWT, feed intake, FI, body weight gain, BWG and feed:gain ratio, F:G) as part of their characterization subsequent to further improvement through selection. 


\section{Materials and Methods}

2.1 Study location: The study was carried out in the Poultry Unit of the Department of Animal Science Teaching and Research Farm, Enugu State University of Science and Technology, Enugu State, Nigeria. The study lasted for five months (20 weeks).

2.2 Experimental materials and Management: A total of 55 mature (> 24 week) male and female local chickens ( 5 males and 50 females) selected from a base population of random breeding Nigerian indigenous chickens (NIC) established in the Department of Animal Science, Enugu State University of Science and Technology, Enugu State were used for the study. The birds were randomly sheared into five groups of 1 cock and 10 hens each to form 5 sire breeding groups in a mating ratio of 1 cock to 10 hens. Eggs were collected, identified according to sire and hatched in a locally fabricated incubator. A total of 250 chicks representing purebred NIC or $\mathrm{G}_{1}$ generation were produced. The chicks were properly identified according to sire, brooded and reared together on deep litter pens from hatch to 20 wks of age. Chicks were fed chicks mash $(18 \% \mathrm{CP}$, $2800 \mathrm{KcalME} / \mathrm{kg}$ ) from day old to 8 wks and growers mash $(16 \% \mathrm{CP}, 2670 \mathrm{KcalME} / \mathrm{kg}$ ) from 9 wks to $20 \mathrm{wks}$ of age. The birds were vaccinated against the endemic poultry diseases (NewCastle disease, infectious bursal disease, and fowl pox) at the appropriate age periods and treated against bacteria and protozoan diseases as and when necessary. They were dewormed using piperazine at 8 and 16 wks of age, respectively. At onset of egg production, the birds were separated and reared according to sex. Four weeks into egg production (28 wks of age), 3-4 cocks were selected from each sire family based on male selection criteria (physical appearance, growth performance and manifestation of maleness). These birds were combined with hens that were equally selected from the same sire family as the cocks (full and half sib sisters) based on good physical appearance and femaleness (good laying performance) to form breeding groups in the ratio of 1 cock: $\leq 10$ hens. Three to four (3-4) replicate breeding groups were established from each sire family. These breeding groups were identified as sire lines (i.e., lines established from sire families) and were used to generate the inbred $\left(\mathrm{G}_{2}\right)$ generation (Table 1). The breeding groups were fed layers mash $(16 \% \mathrm{CP}, 2650 \mathrm{KcalME} / \mathrm{kg})$ from 4 weeks of onset of egg production (at $\approx 30 \%$ laying performance). Eggs were collected and set to hatch. The hatched chicks were identified according to sire line and brooded and reared as described for $\mathrm{G}_{1}$ generation. As much as was possible equal management attention was given to the experimental groups and to birds belonging to the different generations.

2.3 Data collection and Analysis: The $G_{1}$ population (progenies from $G_{0}$ sire breeding groups) and the $G_{2}$ population (inbred progenies of sire families) were evaluated for growth performance, feed intake and feed:gain. Body weight was measured at hatch and bi-weekly for 20 weeks. Daily feed intake was determined as the difference between quantity supplied and the left over after $24 \mathrm{~h}$ divided by the number of birds in a group while daily weight gain was determined as the difference between two consecutive body weight values divided by the number of days in the interval. Feed:Gain ratio was determine as the gramme feed per gramme gain for the age period under consideration. Data generated from $\mathrm{G}_{1}$ population (sire families) were analyzed according to the paternal half sib Analysis of Variance using a sire model to determine the effect of sire on the parameters measured. The statistical model was:

$X_{i j}=\mu+S_{i}+\ell_{i j}$

Where $X_{\mathrm{ij}}$ is an observation, $\mu$ is common mean, $S_{\mathrm{i}}$ is effect of sire and $\ell_{\mathrm{ij}}$ is random error term.

Data from the inbred progeny population $\left(\mathrm{G}_{2}\right.$ generation) were similarly subjected to analysis of variance (ANOVA) to determine the effect of sire line on the parameters using the following statistical model:

$X_{\mathrm{jk}}=\mu+L_{\mathrm{j}}+\ell_{\mathrm{jk}}$

Where $\ell_{\mathrm{jk}}$ is as defined previously, $\mathrm{X}_{\mathrm{jk}}$ is the $\mathrm{k}^{\text {th }}$ observation in the $\mathrm{j}^{\text {th }}$ line, $\mu$ is common mean for lines, and $L_{j}$ is line effect. Significantly different sire and sire line effects were separated using the Duncan New Multiple Range test [13]. Comparison between sire family (parent population, $\mathrm{G}_{1} \mathrm{~S}_{\mathrm{i}}$ ) and corresponding progeny population $\left(\mathrm{G}_{2} \mathrm{~L}_{\mathrm{i}}\right)$ and between $\mathrm{G}_{1}$ and $\mathrm{G}_{2}$ generations was performed using the independent samples t-test. The coefficient of inbreeding $\left(\mathrm{F}_{\mathrm{x}}\right)$ in the inbred generation was calculated using the above relationship by [14]:

$$
F x=1 / 2\left(\frac{1}{N m A m}+\frac{1}{N f A f}\right)
$$

Where, $\mathrm{Nm}$ and $\mathrm{Nf}$ is the number of males and females, respectively and Am and Af the age of males and females at breeding, respectively.

\section{Results and Discussion}

The population structure, mating arrangement and number of chicks for $G_{1}$ and $G_{2}$ generations is presented in TABLE 1 while TABLE 2 presents the growth performance of $G_{1}$ (sire families) and $G_{2}$ (sire lines, $\mathrm{L}_{\mathrm{i}}$ ) of the NIC at the various age periods. Average inbreeding coefficient of $\mathrm{G}_{2}$ generation was $2.39 \%$ (range, 2.00-2.65\%). Body weight differed significantly ( $\mathrm{P} \square 0.05$ ) among sire groups and sire lines. Generally, progenies of sires 1,2 , and 4 had the highest body weights across the age periods compared to those of 3 , and 5 . 
The same trend was observed in their progenies with those belonging to sire lines 1,2 , and 4 surpassing (P $\square$ 0.05 ) those of lines 3 , and 5 in body weight except at hatch at which no difference was observed among the sire lines in body weight. The similar trend in body weight observed across generations between sire groups in $G_{1}$ generation and their lines in $G_{2}$ generation shows that the birds in $G_{1}$ generation bred true and that sire body weight lines (or inbred lines) could be established in the local chicken for use in further crossbreeding schemes. Table 2 also shows a general reduction in the standard error of means in $\mathrm{G}_{2}$ birds compared to the $\mathrm{G}_{1}$ population or a greater cluster of body weight values around the mean in the $\mathrm{G}_{2}$ population indicating a reduction in variation probably due to the effect of inbreeding which reduces genetic variation within populations [15] as expected when full and half sib mating scheme is employed as in the present study.

Feed intake did not differ significantly between sire families in $\mathrm{G}_{1}$ generation except at wk 16 but significant ( $\mathrm{P} \square$ 0.05) variation in feed inake was observed across the age periods in $\mathrm{G}_{2}$ generation although no particular pattern or trend was apparent among the sire lines across the age periods (TABLE 3). On the average, $\mathrm{G}_{1}$ birds consumed $18.66 \pm 0.24 \mathrm{~g}$ feed per day per bird (range: $17.84 \pm 0.46-19.42 \pm 0.55 \mathrm{~g}$ ) during the first 4 weeks of life, $68.22 \pm 0.67 \mathrm{~g}$ (range: $65.80 \pm 1.77-70.87 \pm 1.45 \mathrm{~g}$ ) and $88.94 \pm 0.90 \mathrm{~g}$ (range: $84.78 \pm 1.80-$ $91.25 \pm 1.39 \mathrm{~g}$ ) during wk 12 and 20, respectively. Feed consumption is a very variable trait modified by genetic and environmental factors. The values obtained for feed intake in $G_{1}$ and $G_{2}$ generations are in agreement with values reported by some other workers on indigenous chickens [16, 17].

Sire groups were generally similar to their inbred progenies in body weight across the age periods (TABLE 4). For instance birds belonging to $\mathrm{G}_{1} \mathrm{~S}_{1}$ surpassed their inbred progenies $\left(\mathrm{G}_{2} \mathrm{~L}_{1}\right)$ in body weight only at hatch $(27.06 \pm 0.41$ vs $24.42 \pm 0.29 \mathrm{~g})$ and at wk $12(671.42 \pm 19.66$ vs $619.85 \pm 18.60 \mathrm{~g})$ while those of $\mathrm{G}_{1} \mathrm{~S}_{4}$ exceeded their progenies $\left(\mathrm{G}_{2} \mathrm{~L}_{4}\right)$ in body weight at wk 20 only $(950.98 \pm 22.05$ vs $888.33 \pm 20.86 \mathrm{~g})$. No significant differences in body weight were observed for other groups across the age periods. The observed similarity in growth performance between $G_{1}$ and $G_{2}$ birds is supported by Udeh and Omeje [7] who reported equivalent body weight and body weight gain at 4,12 , and $20 \mathrm{wk}$ of age, respectively in inbred exotic and local chickens. These results support our earlier submission that the $\mathrm{G}_{1}$ birds bred true and this indicates high additive genetic effect on growth performance in the NIC. The results also indicate that growth was not significantly affected by within line mating employed in production of the $\mathrm{G}_{2}$ progenies and that inbreeding could be carried out for more generations in the population with minimal reduction in growth performance.

Significant $\left(P \square 0.05\right.$ ) differences were observed in feed intake between $G_{1} S_{1}$ and $G_{2} L_{1}$ at 20 wk $(88.47 \pm 1.80$ vs $95.24 \pm 1.44 \mathrm{~g})$ and between $\mathrm{G}_{1} \mathrm{~S}_{5}$ and $\mathrm{G}_{2} \mathrm{~L}_{5}$ birds at 4 (17.84 \pm 0.46 vs $\left.21.64 \pm 0.63 \mathrm{~g}\right), 8$ (42.79 \pm 1.12 vs $38.83 \pm 0.77 \mathrm{~g})$, and 20 wk $(84.78 \pm 1.80$ vs $90.16 \pm 1.87 \mathrm{~g})$ (TABLE 5). Other groups were generally similar in feed intake. These results show that feed intake was not significantly depressed in the inbred groups and this could be related to the equivalent growth performance observed between the $G_{1}$ population and their inbred progenies. The results also show that feed intake may not be liable to inbreeding depression in accord with Wiener [18] and Udeh and Omeje [7].

The generational mean comparison $\left(\mathrm{G}_{1} \mathrm{vs} \mathrm{G}_{2}\right)$ for growth parameters (body weight, feed intake, body weight gain and feed:gain ratio) are presented in TABLE 6. Significant ( $\mathrm{P} \square$ 0.05) differences in body weight were observed at hatch $(26.48 \pm 0.17$ vs $25.17 \pm 0.13 \mathrm{~g}$ or $1.31 \mathrm{~g}$ difference), 12 and 20 wks of age $(624.83 \pm$ 3.28 vs $600.43 \pm 6.90 \mathrm{~g}$, or $24.40 \mathrm{~g}$ difference and $895.91 \pm 11.40$ vs $860.08 \pm 9.29 \mathrm{~g}$ or $35.83 \mathrm{~g}$ difference, respectively). The percent changes (reduction) in body weight at these periods were hence 4.95, 3.91 and 4.00, respectively. Feed intake differed significantly $(\mathrm{P} \square$ 0.05) at wks 4 , and 20 (18.66 \pm 0.24 vs $20.20 \pm 0.29 \mathrm{~g}$ and $88.94 \pm 0.90$ vs $92.78 \pm 0.81 \mathrm{~g}$, respectively). Thus $\mathrm{G}_{2}$ birds consumed 8.25 and $4.32 \%$ more feeds, respectively at these age periods than their $\mathrm{G}_{1}$ parents. Body weight gain and feed:gain ratio differed significantly (P $\left.\square 0.05\right)$ between $G_{1}$ and $G_{2}$ generations across the entire age periods (wk 4 to 20, respectively) and were depressed in the $\mathrm{G}_{2}$ generation with a range of 13.72 to $24.97 \%$ for body weight gain and 19.93 to $23.97 \%$ for feed:gain ratio. The depressed body weight at hatch in inbred group could result from reduced egg size in this group as was alluded to by Udeh and Omeje [7]. The response obtained at wk 12 could relate to a delay in the initiation of the effect of genes responsible for transition from juvenile to adult body weight. It had been reported the point of inflection for NIC to be $12 \mathrm{wk}$, at which birds transit from juvenile to mature growth phase (Omeje, S. S. 1, 1983, Msc. Dissertation, University of Nigeria, Nsukka, unpublished). In addition, inbreeding has been shown to delay sexual maturity and attainment of mature body weight in animals [19]. Abdou et al. [20] also reported percentage reductions in body weight at $4,8,12$, and 16 weeks in three lines of inbred Fayoumi chickens in which inbreeding coefficients ranged from 6.25 to $37.5 \%$. Szwaczkowski et al. [19] reported a reduction of about $3.37 \mathrm{~g}$ in the body weight of egg type chickens based on partial linear regression and a reduction of $39.04 \mathrm{~g}$ per $10 \%$ of inbreeding. These reports are at variance with the results obtained in the present study probably as a result of the genetic and population structure of the experimental birds. For instance, the Fayoumi is an improved breed of chicken with many generations of directional selection and mating while the local chickens employed in the present study came from an unselected and random breeding base population with inbreeding coefficient of zero. Furuta et al. [21] found a difference of $10 \mathrm{~g}$ in feed consumption of $3^{\text {rd }}$ generation purebred 
egg chickens compared to the $2^{\text {nd }}$ generation population which is higher than the values reported in the present study.

Table 1: Population structure and coefficient of inbreeding (Fx) for G0 and G1 generations of Nigerian indigenous chickens used for the study

\begin{tabular}{|c|c|c|c|c|c|c|c|}
\hline \multicolumn{4}{|c|}{ G0 generation (parents) } & \multicolumn{4}{|c|}{ G1 generation (parents) } \\
\hline Sire group $(\mathrm{Si})$ & Dam & Fx (\%) & Chicks (G1) & Sire line $(\mathrm{G} 1)$ & $\operatorname{Dam}(\mathrm{G} 1)$ & $\mathrm{Fx}(\%)$ & $\begin{array}{l}\text { Chicks } \\
\text { (G2) }\end{array}$ \\
\hline S1 & 10 & 0.00 & 60 & 4 & 40 & 2.00 & 58 \\
\hline $\mathrm{S} 2$ & 10 & 0.00 & 40 & 3 & 30 & 2.65 & 50 \\
\hline S3 & 10 & 0.00 & 50 & 3 & 30 & 2.65 & 45 \\
\hline S4 & 10 & 0.00 & 50 & 3 & 30 & 2.65 & 50 \\
\hline S5 & 10 & 0.00 & 45 & 4 & 40 & 2.00 & 47 \\
\hline Average Fx $(\%)$ & & & & & & 2.39 & \\
\hline
\end{tabular}

Table 2: Effect of sire group and sire line on body weight $(\mathrm{g})$ of purebred Nigerian indigenous chicken at various age periods

\begin{tabular}{|c|c|c|c|c|c|}
\hline \multicolumn{6}{|c|}{ Sire group (G1 generation) } \\
\hline Age (wk) & S1 & $\mathrm{S} 2$ & S3 & S4 & S5 \\
\hline 0 & $27.06 \pm 0.41 \mathrm{a}$ & $26.98 \pm 0.43 a$ & $25.56 \pm 0.33 b$ & $27.12 \pm 0.32 \mathrm{a}$ & $25.68 \pm 0.29 b$ \\
\hline 4 & $168.22 \pm 3.36 \mathrm{ab}$ & $170.31 \pm 3.86 \mathrm{a}$ & $160.36 \pm 3.18 \mathrm{ab}$ & $177.33 \pm 3.29 \mathrm{a}$ & $160.37 \pm 3.17 b$ \\
\hline 12 & $671.42 \pm 19.66 \mathrm{a}$ & $640.82 \pm 18.66 a$ & $591.79 \pm 15.94 b$ & $660.00 \pm 18.92 \mathrm{a}$ & $564.60 \pm 13.64 b$ \\
\hline 16 & $750.15 \pm 25.65 a$ & $794.33 \pm 22.58 a$ & $666.62 \pm 18.34 b$ & $759.86 \pm 21.65 a$ & $647.15 \pm 17.37 b$ \\
\hline 20 & $937.88 \pm 31.34 \mathrm{a}$ & $940.00 \pm 26.08 \mathrm{a}$ & $831.50 \pm 20.76 b$ & $950.98 \pm 22.05 \mathrm{a}$ & $821.95 \pm 18.54 b$ \\
\hline Age (wk) & L1 & L2 & L3 & $\mathrm{L} 4$ & L5 \\
\hline 0 & $24.42 \pm 0.29$ & $25.04 \pm 0.31$ & $25.06 \pm 0.27$ & $26.22 \pm 0.28$ & $25.19 \pm 0.25$ \\
\hline 4 & $166.65 \pm 2.88 \mathrm{a}$ & $167.11 \pm 3.00 \mathrm{a}$ & $154.94 \pm 2.89 b$ & $172.73 \pm 2.62 \mathrm{a}$ & $161.67 \pm 2.36 \mathrm{ab}$ \\
\hline 8 & $320.40 \pm 7.90 \mathrm{a}$ & $321.80 \pm 6.86 \mathrm{a}$ & $300.34 \pm 7.05 b$ & $331.42 \pm 8.21 \mathrm{a}$ & $288.68 \pm 5.35 b$ \\
\hline 12 & $619.85 \pm 18.60 \mathrm{a}$ & $626.89 \pm 12.69 a$ & $567.79 \pm 14.33 b$ & $623.68 \pm 16.51 \mathrm{a}$ & $563.48 \pm 12.35 b$ \\
\hline 16 & $768.33 \pm 22.34 \mathrm{a}$ & $741.93 \pm 18.50 \mathrm{a}$ & $642.74 \pm 17.31 b$ & $741.06 \pm 19.42 \mathrm{a}$ & $647.42 \pm 14.43 b$ \\
\hline
\end{tabular}

$\mathrm{a}, \mathrm{b}$ : means in the same row having different superscripts are significantly different $(\mathrm{P}<0.05)$.

Table 3: Effect of sire group and sire line on daily feed intake $(\mathrm{g})$ of purebred Nigerian indigenous chickens at various age periods

\begin{tabular}{|c|c|c|c|c|c|}
\hline \multicolumn{6}{|c|}{ Sire group (G1 generation) } \\
\hline $\begin{array}{l}\text { Age } \\
\text { (wk) }\end{array}$ & $\mathrm{S} 1$ & $\mathrm{~S} 2$ & S3 & S4 & S5 \\
\hline 4 & $18.72 \pm 0.50$ & $19.42 \pm 0.55$ & $19.15 \pm 0.54$ & $18.00 \pm 0.52$ & $17.84 \pm 0.46$ \\
\hline 8 & $39.52 \pm 0.85$ & $40.50 \pm 1.03$ & $41.87 \pm 0.90$ & $42.22 \pm 1.02$ & $42.79 \pm 1.12$ \\
\hline 12 & $69.59 \pm 1.52$ & $66.50 \pm 1.29$ & $67.82 \pm 1.14$ & $65.80 \pm 1.77$ & $70.87 \pm 1.45$ \\
\hline 16 & $77.56 \pm 0.76 b$ & $78.36 \pm 0.78 \mathrm{ab}$ & $77.31 \pm 0.69 b$ & $76.00 \pm 0.94 b$ & $80.94 \pm 1.79 a$ \\
\hline 20 & $88.47 \pm 1.80$ & $88.94 \pm 2.55$ & $91.25 \pm 1.39$ & $91.04 \pm 2.45$ & $84.78 \pm 1.80$ \\
\hline \multicolumn{6}{|c|}{ Sire line (G2 generation) } \\
\hline $\begin{array}{l}\text { Age } \\
\text { (wk) }\end{array}$ & L1 & L2 & L3 & L4 & L5 \\
\hline 4 & $19.83 \pm 0.63 \mathrm{ab}$ & $20.58 \pm 0.74 a$ & $20.26 \pm 0.58 \mathrm{a}$ & $18.67 \pm 0.47 b$ & $21.64 \pm 0.63 a$ \\
\hline 8 & $38.08 \pm 1.00 \mathrm{c}$ & $41.00 \pm 0.77 \mathrm{ab}$ & $42.23 \pm 1.04 \mathrm{a}$ & $41.76 \pm 0.83 a$ & $38.83 \pm 0.77 b c$ \\
\hline 12 & $67.39 \pm 1.32 b$ & $69.64 \pm 1.38 \mathrm{ab}$ & $66.16 \pm 1.38 b$ & $66.15 \pm 1.22 b$ & $70.89 \pm 1.34 \mathrm{a}$ \\
\hline 16 & $79.74 \pm 0.79 a$ & $78.35 \pm 0.92 \mathrm{a}$ & $79.60 \pm 1.46 a$ & $75.00 \pm 1.86 b$ & $78.19 \pm 0.65 a$ \\
\hline 20 & $95.24 \pm 1.44 \mathrm{a}$ & $90.13 \pm 2.10 b$ & $94.65 \pm 1.88 \mathrm{a}$ & $93.02 \pm 1.68 \mathrm{ab}$ & $90.16 \pm 1.87 \mathrm{~b}$ \\
\hline
\end{tabular}

Table 4 Comparison between sire groups (G1Si) and sire lines (G2Li) for body weight (g) across the age periods

\begin{tabular}{lllllll}
\hline Age (wk) & & & & \\
\hline Group & 0 & 4 & 8 & 12 & 16 & 20 \\
\hline G1S1 & $27.06 \pm 0.41 \mathrm{a}$ & $168.22 \pm 3.36$ & $331.67 \pm 9.68$ & $671.42 \pm 19.66 \mathrm{a}$ & $750.15 \pm 25.65$ & $937.88 \pm 31.34$ \\
G2L1 & $24.42 \pm 0.29 \mathrm{~b}$ & $166.65 \pm 2.88$ & $320.40 \pm 7.90$ & $619.85 \pm 18.60 \mathrm{~b}$ & $768.33 \pm 22.34$ & $887.12 \pm 24.09$ \\
& & & & & & \\
G1S2 & $26.98 \pm 0.43$ & $170.31 \pm 3.38$ & $335.79 \pm 10.89$ & $640.82 \pm 18.66$ & $794.33 \pm 22.58 \mathrm{a}$ & $940.00 \pm 26.08$ \\
G2L2 & $25.04 \pm 0.31$ & $167.11 \pm 3.00$ & $321.80 \pm 6.86$ & $626.89 \pm 12.69$ & $741.93 \pm 18.50 \mathrm{~b}$ & $890.12 \pm 21.54$ \\
& & & & & & \\
G1S3 & $25.56 \pm 0.33$ & $160.36 \pm 3.18$ & $311.42 \pm 8.75$ & $591.79 \pm 15.94$ & $666.62 \pm 18.34$ & $813.50 \pm 20.76$ \\
G2L3 & $25.06 \pm 0.27$ & $154.94 \pm 2.89$ & $300.34 \pm 7.05$ & $567.79 \pm 14.33$ & $642.74 \pm 17.31$ & $809.88 \pm 17.58$ \\
& & & & & & \\
G1S4 & $27.12 \pm 0.32$ & $177.33 \pm 3.29$ & $332.95 \pm 9.10$ & $660.00 \pm 18.92$ & $759.86 \pm 21.65$ & $950.98 \pm 22.05 \mathrm{a}$ \\
G2L4 & $26.22 \pm 0.28$ & $172.73 \pm 2.62$ & $331.42 \pm 8.21$ & $623.68 \pm 16.51$ & $741.06 \pm 20.86$ & $888.33 \pm 20.86 \mathrm{~b}$
\end{tabular}




\begin{tabular}{llllllll} 
G1S5 & $25.68 \pm 0.29$ & $160.37 \pm 3.17$ & $291.98 \pm 6.65$ & $564.60 \pm 13.64$ & $647.15 \pm 17.37$ & $821.95 \pm 18.54$ \\
G2L5 & $25.19 \pm 0.25$ & $161.67 \pm 2.36$ & $288.68 \pm 5.35$ & $563.48 \pm 12.35$ & $647.42 \pm 14.43$ & $829.55 \pm 15.00$ \\
\hline
\end{tabular}

Table 5: Comparison between sire groups and sire lines for feed intake $(\mathrm{g})$ across age periods

\begin{tabular}{|c|c|c|c|c|c|}
\hline \multicolumn{6}{|c|}{ Age (wk) } \\
\hline Group & 4 & 8 & 12 & 16 & 20 \\
\hline G1S1 & $18.72 \pm 0.50$ & $39.52 \pm 0.85$ & $69.59 \pm 1.57$ & $77.56 \pm 0.76$ & $88.47 \pm 1.80 a$ \\
\hline G2L1 & $19.83 \pm 0.63$ & $38.08 \pm 1.00$ & $67.39 \pm 1.32$ & $79.74 \pm 0.79$ & $95.24 \pm 1.44 b$ \\
\hline G1S2 & $19.42 \pm 0.55$ & $40.50 \pm 1.03$ & $66.50 \pm 1.29$ & $78.36 \pm 0.78$ & $88.94 \pm 2.55$ \\
\hline G2L2 & $20.58 \pm 0.74$ & $41.00 \pm 0.77$ & $69.64 \pm 1.38$ & $78.35 \pm 0.92$ & $90.13 \pm 2.10$ \\
\hline G1S3 & $19.15 \pm 0.54$ & $41.87 \pm 0.90$ & $67.82 \pm 1.14$ & $77.31 \pm 0.69$ & $91.25 \pm 1.39$ \\
\hline G2L3 & $20.26 \pm 0.58$ & $42.23 \pm 1.04$ & $66.16 \pm 1.38$ & $79.60 \pm 1.46$ & $94.65 \pm 1.88$ \\
\hline G1S4 & $18.00 \pm 0.52$ & $42.23 \pm 1.02$ & $65.80 \pm 1.77$ & $76.00 \pm 0.94$ & $91.04 \pm 2.45$ \\
\hline G2L4 & $18.67 \pm 0.47$ & $41.76 \pm 0.83$ & $66.15 \pm 1.22$ & $75.00 \pm 0.86$ & $93.02 \pm 1.68$ \\
\hline G1S5 & $17.84 \pm 0.46 a$ & $42.79 \pm 1.12 \mathrm{a}$ & $70.78 \pm 1.45$ & $80.94 \pm 1.79$ & $84.78 \pm 1.80 a$ \\
\hline G2L5 & $21.64 \pm 0.63 b$ & $38.83 \pm 0.77 b$ & $70.89 \pm 1.34$ & $78.19 \pm 0.65$ & $90.16 \pm 1.87 b$ \\
\hline
\end{tabular}

a, b: Different superscripts indicate significantly different means $(\mathrm{P}<0.05)$.

Table 6: Comparison between generations for growth parameters across age periods

\begin{tabular}{|c|c|c|c|c|c|c|}
\hline & & & Age (wk) & & & \\
\hline GEN & 0 & 4 & 8 & 12 & 16 & 20 \\
\hline \multicolumn{7}{|c|}{ Body weight (g) } \\
\hline G1 & $26.48 \pm 0.17 a$ & $167.44 \pm 1.56$ & $320.06 \pm 4.16$ & $624.83 \pm 3.28 \mathrm{a}$ & $719.64 \pm 10.20$ & $895.91 \pm 11.40 \mathrm{a}$ \\
\hline $\mathrm{G} 2$ & $25.17 \pm 0.13 b$ & $164.40 \pm 1.33$ & $312.66 \pm 3.36$ & $600.43 \pm 6.90 b$ & $706.92 \pm 9.09$ & $860.08 \pm 9.29 b$ \\
\hline$\% \Delta^{* *}$ & $-4.95 *$ & -1.82 & -2.31 & $-3.91 *$ & -1.77 & $-4.00 *$ \\
\hline \multicolumn{7}{|c|}{ Feed intake $(\mathrm{g})$} \\
\hline G1 & NA & $18.66 \pm 0.24 \mathrm{a}$ & $41.38 \pm 0.45$ & $68.22 \pm 0.66$ & $78.10 \pm 0.51$ & $88.94 \pm 0.90 \mathrm{a}$ \\
\hline $\mathrm{G} 2$ & NA & $20.20 \pm 0.29 b$ & $40.28 \pm 0.43$ & $68.02 \pm 0.62$ & $78.24 \pm 0.47$ & $92.78 \pm 0.81 b$ \\
\hline$\% \Delta$ & & $8.25^{*}$ & -2.66 & -0.29 & 0.18 & $4.32 *$ \\
\hline \multicolumn{7}{|c|}{ Body weight gain (g) } \\
\hline G1 & NA & $6.27 \pm 0.18 \mathrm{a}$ & $8.05 \pm 0.22 \mathrm{a}$ & $9.70 \pm 0.24 \mathrm{a}$ & $5.66 \pm 0.17 \mathrm{a}$ & $7.32 \pm 0.22 \mathrm{a}$ \\
\hline $\mathrm{G} 2$ & NA & $5.41 \pm 0.09 b$ & $6.04 \pm 0.14 b$ & $8.01 \pm 0.18 b$ & $4.72 \pm 0.14 b$ & $6.06 \pm 0.14 b$ \\
\hline$\% \Delta$ & & $-13.72 *$ & $-24.97 *$ & $-17.42 *$ & $-16.61 *$ & $-17.21 *$ \\
\hline \multicolumn{7}{|c|}{ Feed:Gain } \\
\hline G1 & NA & $3.18 \pm 0.11 \mathrm{a}$ & $5.47 \pm 0.19 a$ & $7.37 \pm 0.21 \mathrm{a}$ & $14.90 \pm 0.56 \mathrm{a}$ & $13.02 \pm 0.51 \mathrm{a}$ \\
\hline $\mathrm{G} 2$ & NA & $3.86 \pm 0.09 b$ & $7.00 \pm 0.17 b$ & $8.89 \pm 0.20 b$ & $17.87 \pm 0.51 b$ & $16.13 \pm 0.44 b$ \\
\hline$\% \Delta$ & & $21.38^{*}$ & $27.97 *$ & $20.62 *$ & $19.93 *$ & $23.89 *$ \\
\hline
\end{tabular}

$\mathrm{a}, \mathrm{b}$ : different superscripts indicate significantly different means $(\mathrm{P}<0.05), \% \Delta$ : Percent change, $*$ : $\mathrm{P} \leq 0.05$. **: negative indicates a decrease while positive indicates an increase (but does not connote improvement).

\section{Conclusion}

The low average inbreeding coefficient $\left(\mathrm{F}_{\mathrm{x}}\right)$ of 0.0239 or $2.39 \%$ in the inbred NIC population and the similarity between parent and inbred progeny growth parameters suggest low inbreeding depression in this population for the traits studied and that inbreeding could be used to establish inbred lines of the Nigerian indigenous chicken which could then be used in crossbreeding schemes to improve productive traits in this population.

\section{References}

[1]. A. G Drucker, V. Gomez, and S. Anderson, The economic valuation of farm animal genetic resources: A survey of available methods. Ecological economics 36, 2001, 1-18.

[2]. D.I.E. Bixby, In situ conservation of livestock and poultry: Why is it necessary? Who will do it? Who will pay for it? Available at http://www.adsa.org/discover/9th\%20Discover/interpretative\%20, 2003.

[3]. FAO Status and trends report on animal genetic resources-2008. In: Information document. CGRFA/WG-ANGR-5/09/inf.7.Rome, 2009. Available at http://www.fao.org/ag/againfo/programmes/en/genetic/documents/

[4]. L. F. Groeneveld, J. A. Lenstra, H. Eding, M. A. Toro, B. Scherf, D. Pilling, R. Negrini, E. K. Finlay, H. Jianlin, E. Groene veld, S. Weigend and The Globaldiv Consortium. Genetic diversity in farm animals-a review. Animal Genetics, 41(suppl. 1) 2010, 6-31.

[5]. Z.. Goraga, M. Nassar, G-P. Schram and G. A. Brockmann, Phenotypic characterization of chicken inbred lines that differ extremely in growth, body composition and egg production traits. Archiv Tierzucht 53, 2010, 337-349.

[6]. S. S. I. Omeje and C. C. Nwosu, Egg production pattern in local chicken and their crosses in the short-term. Nig. J. Anim. Prod., 10, 1983, 91-96.

[7]. I. Udeh and S. S. I. Omeje, Growth and short term egg production of two exotic (egg type) and the local chickens compared with their F1 inbred progenies. Int. J. Poult. Sci. 10 (3), 2011, 221-224. 
[8]. N. Deep and S. J. Lamont, Genetic architecture of growth and body composition in unique chicken populations. The American Genetic Association 93, 2002, 107-118.

[9]. Gura S. Livestock Genetics Companies, Concentration and Proprietary strartegies of an emerging power in the global food economy. League for pastoral peoples and indigenous livestock Development. Ober-Ramstadt, Germany. 2007, Available at http://www. Pastoralpeoples.org/docs/livestockgenetics en.pdf

[10]. S. M. Lonergan, N. Deep, C. A. Fedler, and S. T. Lamont, Breast meat quality and composition in unique chicken populations. Poult. Sci. 82, 2003, 1990-1994.

[11]. H. R. Juul-Madsen, T. S. Dalganard, C. M. Rontved, K. H. Jensen, N. Bumstead, Immune response to killed infectious bursal disease virus vaccine in inbred chicken lines with different major histocompatibility complex haplotypes. Poult. Sci. 85, 2006, 986998.

[12]. D. K. Kim, H. S. Lillehoj, Y. H. Hong, D. W. Park, S. J. Lamont, J. Y. Han, E. P. Lillehoj, Imme-related gene expression in two Bcomplex disparate genetically inbred Fayoumi chicken lines following Eimeria maxima infection. Poult. Sci. 87, 2008 , 433-443.

[13]. D.B. Duncan, New Multiple Range Test. Biometrics 11, 1955, 1-42.

[14]. J. S. Gavora, A. Emesly and R. K. Cole, Inbreeding in 35 generations of development of cornel strain of Leghorn. Poult. Sci., 38, 1979, 1133-1136.

[15]. F. Pirchner, Population Genetics in Animal Breeding ( $2^{\text {nd }}$ ed. $), 1983$. Plunum Press New York and London.

[16]. A. M. Kingori, J. K. Tuitoek, H. K Muiruri and A. M. Wachira, Protein requirement of growing indigenous chickens during 14-21 weeks growing period. South African Journal of Animal Science 33 (2), 2003, 78-82.

[17]. H. Hassen, P. W. C. Neser, T. Dessie, A. deKock and E. Van Marle-Koster, Studies on the growth performance of of native chicken ecotypes and RIR chicken under improved management system in Northeast Ethiopia. Livestock Research for Rural Development 18 (6), 2006, htm.

[18]. G. Weiner, The tropical Agriculturist, Animal breeding. Macmillian Press, LTD London, 1994, 208.

[19]. T. Szwaczkowski, K. Cywa-Benko and S. Wezyk, Curvilinear inbreeding effects on some performance traits in laying hens. J. Appl. Genet. 45 (3), 2004, 343-345.

[20]. F. H. Abdou, M. Soltan, M. AbdEllatif and H. Ayoub, Sensitivity of inbred Fayoumi chicks to seasonal variations. Ann. Genet. Sel. Anim., 9 (4), 1977, 423-429.

[21]. K. Furuta, H. Ohashi, J. Obana and S. Sato, Performance of 3 successive generations of specified-pathogen-free chickens maintained as a closed flock. Laboratory Animals 14, 1980, 107-112. 